\section{Emerging techniques to treat corneal neovascularisation}

Michaelson ${ }^{2,3}$ was the first to suggest that a diffusible factor liberated by retinal or corneal tissue would stimulate vascular growth and development. ${ }^{2,3}$ Subsequently, a number of factors to activate and guide healthy or pathological vascularisation were identified. This review intends to provide an overview of important factors and potential therapeutic targets in the context of corneal neovascularisation.

Vascular growth during development entails vasculogenesis and angiogenesis

During ontogenesis, de novo formation of a capillary lattice occurs within each organ by a process referred to as vasculogenesis. ${ }^{4,5}$ This involves blood vessel precursor cells called angioblasts, sharing with haematopoietic cells a common progenitor of mesodermal origin, the haemangioblast. ${ }^{6}$ Aggregates of angioblasts differentiate into endothelial cells (ECs) that line a lumen containing blood precursor cells. Fusion of these 'blood islands' forms the so-called primary capillary plexus.

Subsequently, additional vessels are formed and the primitive network is remodelled through a process termed angiogenesis. It entails sprouting and intussusception (splitting), functional maturation of ECs, and recruitment of smooth muscle cells or pericytes. This also lends primitive vessels the distinct properties of arteries and veins. ${ }^{5}$

To enable sprouting from pre-established vessels, cell-cell contacts between ECs are loosened, and the extracellular matrix (ECM) is degraded. ${ }^{7}$ ECs can then extend filopodia, migrate, and lead vascular growth in response to gradients of environmental mitogens. ${ }^{8}$ Promotion and inhibition of vascularisation is orchestrated with the help of such pro- and antiangiogenic mediators, both during and after development. ${ }^{9,10}$ Vasculogenesis is seen

Received: 13 April 2011 Accepted in revised form: 27 August 2011 Published online: 7 October 2011

\section{Introduction}

Our ability to see is a highly specialised architecture of the human eye. Each ocular tasks The perfectly organised vascular tree of the retinal circulation and the avascularity of the cornea serve as examples. Where the delicate homeostasis of vessel growth and inhibition areas that were previously avascular can disrupt visual function and cause disease. Indeed, abnormal vascularisation underlies or accompanies some important ocular pathologies, including the neovascular form of age-related macular degeneration, proliferative diabetic retinopathy, retinopathy of prematurity, retinal vein occlusion, and corneal neovascularisation. The public health impact of ocular

neovascularisation therefore is significant. ${ }^{1}$
\end{abstract}




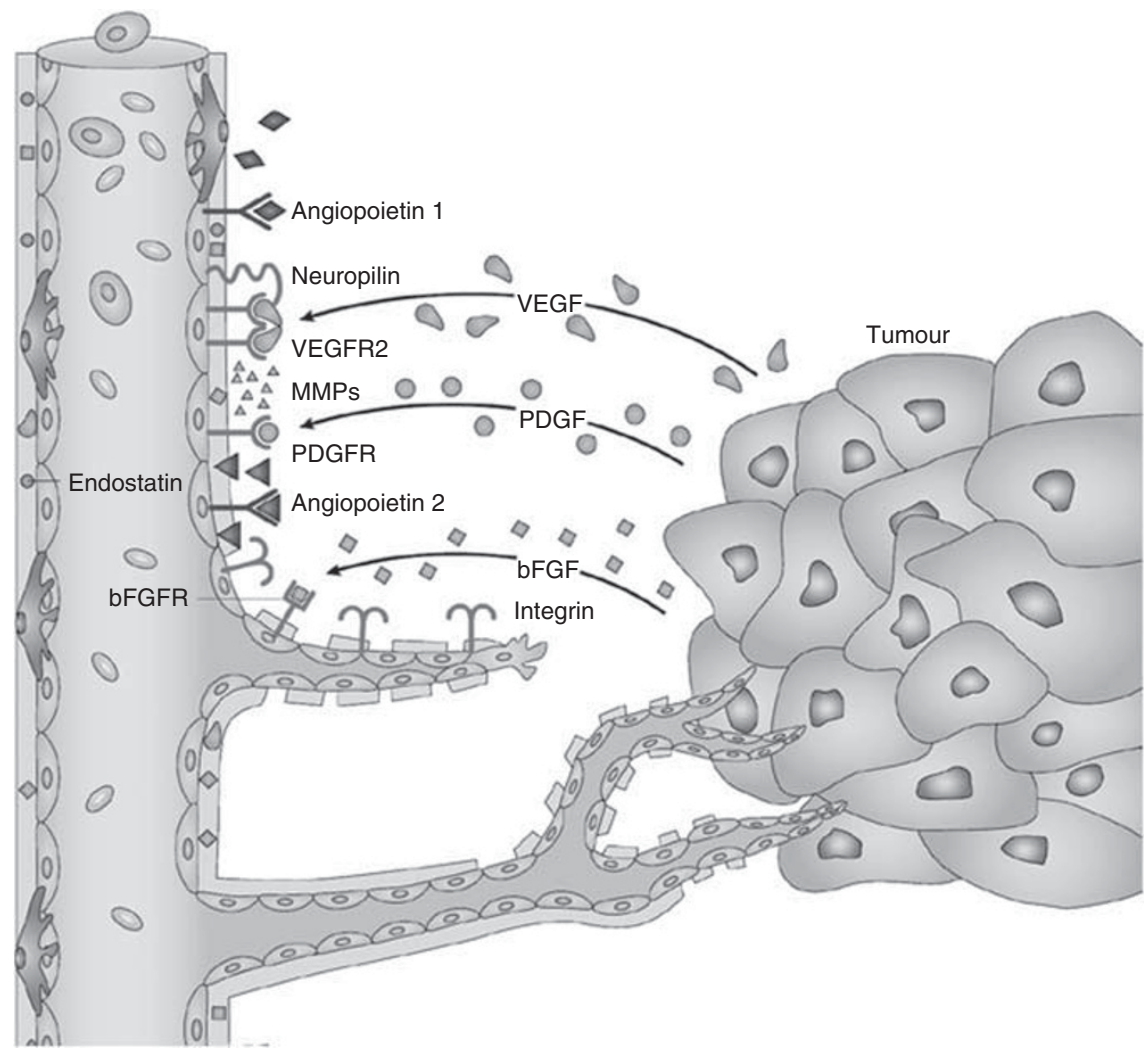

Figure 1 Soluble angiogenic factors are released from tumour cells to induce and regulate key steps in angiogenesis. Many of these factors have also been found to have a role in ocular and, more specifically, corneal neovascularisation. Angiopoietin- 1 binds to endothelial Tie-2 receptors to stabilise the established vasculature. Angiopoietin-2, however, which is secreted by tumour cells, and which competes with angiopoietin- 1 for the Tie-2 receptor, increases vascular basal membrane degradation and EC migration. Vascular endothelial growth factor (VEGF), platelet-derived growth factor (PDGF), and basic fibroblast growth factor (bFGF) may also be secreted by tumour cells, and exert pro-angiogenic effects via their respective EC receptors (with VEGF-receptors requiring assistance from neuropilins). Tumours or ECs may also release matrix metalloproteinases (MMPs). These have some pro-angiogenic effects, but also cleave antiangiogenic endostatin from collagen XVIII of the extracellular matrix, and angiostatin from circulating plasminogen (not depicted; adapted from Folkman, ${ }^{100}$ with permission from Macmillan Publishers Ltd).

predominantly during embryogenesis, whereas angiogenesis occurs also in adults in the context of wound healing, pregnancy, and uterine cycling. ${ }^{11}$ However, angiogenesis has also been found to have a major role in pathological processes such as tumour growth and metastasis, as well as ocular neovascularisation (Figure 1). ${ }^{10,12}$ Mechanisms and mediators of pathologic angiogenesis are thought to differ somewhat from physiological angiogenesis, exemplified by the fact that the latter does not usually carry an inflammatory component. ${ }^{13}$ In a rat model, angiogenesis has been identified as the underlying mechanism of corneal neovascularisation. Here, initial events are vasodilation of the limbal vessels and recruitment of leucocytes (which release additional pro-angiogenic mediators), followed by vascular sprouts, which emerge from pericorneal venules and capillaries. ${ }^{14}$

\section{Corneal avascularity is the result of an active regulatory process}

Although vascularisation is vital for the survival of most tissues, some structures require avascularity to ensure proper functioning. These include cartilage, heart valves, and in the eye cornea, vitreous and lens. ${ }^{15-18}$ In these tissues, mechanisms are in place to inhibit ingrowth of blood vessels. To maintain what has been termed the 'angiogenic privilege' in the cornea, a delicate balance exists between pro- and antiangiogenic factors (Figure 2). Pro-angiogenic factors include fibroblast growth factor (FGF), vascular endothelial growth factor (VEGF), platelet-derived growth factor (PDGF), and angiopoietin, among others. Factors with antiangiogenic properties include endostatin, angiostatin, thrombospondin, pigment epithelium-derived factor, and others. ${ }^{19}$ Their balance is actively maintained, as exemplified by 


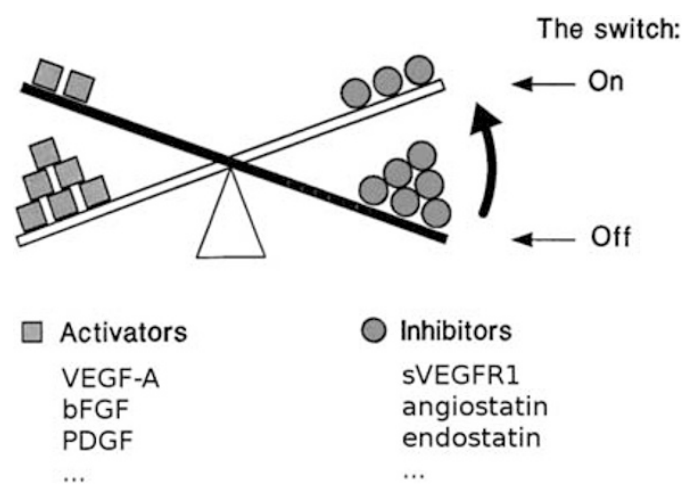

Figure 2 The 'angiogenic switch' hypothesis. In health or mild disease, pro-angiogenic factors are counteracted by the inhibitors of angiogenesis. Quiescent vasculature is stimulated to cause neovascularisation, if increasing levels of activators of angiogenesis tilt the balance towards vessel growth. Likewise, increased presence of inhibiting factors or removal of activators can tilt it back towards maintaining avascularity. VEGF, vascular endothelial growth factor; bFGF, basic fibroblast growth factor; PDGF, platelet-derived growth factor; sVEGFR1, soluble VEGF receptor 1. (Adapted from Hanahan and Folkman, ${ }^{12}$ with permission from Elsevier).

evidence, showing that after corneal injury, antiangiogenic factors are upregulated to maintain corneal avascularity. ${ }^{20}$ However, these mechanisms are not fail-proof, and numerous clinical conditions are known to involve ingrowth of vessels into the corneal tissue. Most pathological processes of the cornea that lead to vascularisation can be assigned to one of the three main categories: hypoxic (mainly contact lens wear), inflammatory (eg, infectious keratitis or corneal graft rejection), and loss of limbal barrier function (limbal stem cell deficiency, for instance, due to aniridia). ${ }^{21-23}$

Presence of aberrant vessels in turn increases corneal oedema and leads to lipid deposition, haemorrhage, and scarring, further compromising corneal transparency and visual acuity. ${ }^{24}$ Neovascularisation also increases the rate of failure and rejection of corneal grafts. ${ }^{25}$ This has been attributed, at least in part, to clinically invisible lymphatic vessels, which abrogate the immunological privilege of the cornea. ${ }^{26,27}$

Although aetiologies of corneal neovascularisation vary, the common endpoint is a breakdown of the angiogenic privilege..$^{28}$ The following sections briefly characterise a selection of prominent pro- and antiangiogenic mediators, which may threaten or maintain this privilege.

\section{Pro-angiogenic factors in the cornea}

VEGF has been shown to be a key mediator of vasculogenesis and angiogenesis. ${ }^{29,30}$ Its important contribution to vascular development is reflected in the fact that the deletion of a single VEGF allele is lethal in the mouse embryo. ${ }^{31}$ Members of the VEGF family promote a number of steps in the process of angiogenesis, including proteolytic activities, vascular EC proliferation and migration, inhibition of EC apoptosis, and recruitment of EC precursors. ${ }^{28,32}$

Particularly VEGF-A is a potent survival factor and mitogen for ECs. ${ }^{33}$ It binds the tyrosine kinase receptors VEGFR-1 and VEGFR-2, with the pro-angiogenic signal being conveyed predominantly via VEGFR-2 in many tissues. ${ }^{34}$ Involvement of VEGF-A in corneal vessel growth was demonstrated in animal models of corneal neovascularisation, using VEGF-A blocking monoclonal antibodies; when implanted into the corneal stroma, these inhibit neovascularisation. ${ }^{35,36}$

VEGF-C and VEGF-D, acting via VEGFR-3, make important contributions to growth and development of lymphatic vessels. Indeed, antibodies against VEGFR-3 specifically block lymphangiogenesis in the cornea. ${ }^{37}$

Expression of VEGF is increased by hypoxia and inflammation. ${ }^{38,39}$ Hence, it is upregulated in the cornea following hypoxic injury, ocular wounding, and during acute inflammation in different animal models. ${ }^{36,40,41}$

FGF is a heparin-binding peptide, which stimulates migration and proliferation of ECs. ${ }^{42,43}$ FGF binds to ECs of corneal blood and lymphatic vessels. ${ }^{44}$ Ellenberg et $a l^{19}$ demonstrated a role of FGF in promoting corneal angiogenesis, and suggested this to occur via upregulation of VEGF. Indeed, interplay between VEGF and FGF was proposed to occur at the receptoral and postreceptoral level. ${ }^{45,46}$ One factor involved in linking the two pathways may be membrane-type 1 matrix metalloproteinase (MMP). Membrane-type $1 \mathrm{MMP}$ was shown to increase FGF-induced VEGF upregulation and corneal neovascularisation in a mouse model and in an in vitro model. ${ }^{47}$

In fact, MMPs appear to be involved in angiogenesis in the most varied ways. For instance, apart from their general abilities to remodel the ECM and pave the way for growing vessels, MMP-9 releases VEGF from the ECM. ${ }^{48}$ However, antiangiogenic properties have also been detected for MMPs, as will be discussed below.

PDGF acts to stabilise vessels by attracting pericyte progenitor cells. ${ }^{49,50}$ It has been suggested that VEGF antagonists are more effective in vessels which lack pericytes. ${ }^{51}$ Hence, a combination of VEGF- and PDGFantagonists could be envisaged to inhibit neovascularisation. Indeed, blocking both VEGF and PDGF pathways was more effective in inhibiting corneal neovascularisation in rabbits than VEGF pathway blockade alone. ${ }^{52}$

Angiopoietins are protein growth factors whose action (via the tyrosine kinase receptor Tie-2) is required for formation of mature blood vessels. ${ }^{9}$ Angiopoietin-1 and 
angiopoietin-2 were found to modulate sensitivity to VEGF (Figure 1). ${ }^{53}$ In the cornea, inhibition of angiopoietin-2 suppressed angiogenesis; however, additional inhibition of angiopoietin-1 yielded no further suppression of angiogenesis. ${ }^{54}$

\section{Antiangiogenic factors in the cornea}

To counteract vasoproliferative effects of VEGF-A, soluble forms of VEGFR-1 are expressed by corneal epithelium. ${ }^{55}$ Ambati et $a l^{55}$ showed that in the absence of soluble VEGFR-1, mice develop corneal neovascularisation. Furthermore, VEGFR-1 is expressed in healthy human corneal epithelium, whereas in neovascularised human corneas, VEGFR-1 expression is significantly reduced. ${ }^{56}$

In addition, VEGFR-3 is ectopically expressed in corneal epithelium. ${ }^{57}$ This acts as a decoy mechanism to neutralise VEGF-C and VEGF-D, classically regarded as lymphangiogenic factors.

A protein showing structural relationship to hypoxiainducible transcription factors (HIF) has been reported to impair HIF1 $\alpha$-mediated expression of VEGF. ${ }^{58}$ Mouse corneal epithelial cells strongly expressed this protein in vitro, particularly under hypoxic conditions. In these cells, expression of VEGF was low even under hypoxic conditions, but increased when the HIF-related protein was antagonised. In vivo, antagonisation induced neovascularisation already at normal levels of oxygen, suggesting an important role in maintaining corneal avascularity.

Pigment epithelium-derived factor has been identified as an important factor opposing ocular angiogenesis. ${ }^{59}$ It is expressed in the corneal tissue, ${ }^{60}$ and was detected in human tear fluid. ${ }^{61}$

The antiangiogenic properties of angiostatin, a fragment of plasminogen, were first shown in the context of tumour growth and metastasis. ${ }^{62}$ Presence of angiostatin was demonstrated in human corneal epithelium, ${ }^{63}$ and in mouse corneas during wound healing. ${ }^{20}$ It was found to inhibit corneal neovascularisation in different rodent models. ${ }^{64}$

Endostatin is a fragment of collagen XVIII, which induces EC apoptosis, ${ }^{65}$ and which is present in human cornea. ${ }^{66}$ MMPs were reported to be involved in generating endostatin via cleavage of collagen; ${ }^{67}$ together with pro-angiogenic properties of these proteolytic enzymes (vide supra), this exemplifies their ambiguous role in angiogenesis.

Thrombospondins are matricellular proteins able to inhibit migration and survival of vascular ECs. ${ }^{68}$ They are expressed in the normal cornea, and both thrombospondin-1 and thrombospondin-2 were found to suppress the inflammation-induced corneal neovascularisation in rodents. ${ }^{69,70}$

\section{Current therapeutic approaches towards corneal neovascularisation}

The method of choice to treat corneal neovascularisation depends on the state of maturation of these vessels. Mature vessels often no longer rely on angiogenic mediators. ${ }^{71,72}$ Here, surgical interventions such as fine-needle cauterisation, first reported by Pillai et $a l_{,}^{73}$ may constitute the most effective treatment. However, during active vessel growth, pharmacological manipulation of molecular cues for vascular ECs suggests itself as a therapeutic approach. It has been suggested from ultrastructural and immunohistochemical analysis of vascularised human corneas that vessel maturation by pericyte recruitment may occur within less than 2 weeks after clinical diagnosis of corneal neovascularisation. ${ }^{74}$ This is likely to limit the time-frame available for successful antiangiogenic therapy. However, blockade of angiogenic growth factors may still be beneficial to prevent further sprouting of vascular ECs in cases in which the angiogenic stimulus persists.

Table 1 provides an overview of current indications for antiangiogenic therapy at the cornea. Anti-inflammatory agents (eg, steroids, cyclosporine A) are a classic means to suppress corneal inflammation and corneal neovascularisation. ${ }^{75}$ On top of their anti-inflammatory properties, steroids have been shown to inhibit proliferation and migration of vascular ECs. ${ }^{19}$ Using a rodent model to compare anti-lymphangiogenic effects of different topically applied corticosteroids, the strongest effect was measured for prednisolone, which may therefore render this substance particularly suitable to

Table 1 Current indications for antiangiogenic therapy ${ }^{\mathrm{a}}$ at the cornea (adapted from Cursiefen $e t \mathrm{l}^{23}$ )

\begin{tabular}{ll}
\hline Infectious keratitis & $\begin{array}{l}\text { Herpetic } \\
\text { Bacterial } \\
\text { Fungal } \\
\text { Parasitic }\end{array}$ \\
Inflammatory & Mucous membrane pemphigoid \\
conditions & $\begin{array}{l}\text { Atopic conjunctivitis } \\
\text { Rosacea } \\
\text { Lyell's syndrome } \\
\text { Stevens-Johnson syndrome }\end{array}$ \\
& $\begin{array}{l}\text { Preoperative conditioning } \\
\text { Postoperative prevention of graft } \\
\text { rejection/failure }\end{array}$ \\
Corneal graft & Limbal stem cell deficiency \\
Loss of limbal & Corneal burns or other injury \\
\hline
\end{tabular}

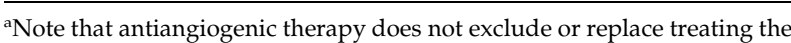
cause of the underlying condition, where applicable. ${ }^{87}$ 
prevent rejection of corneal allografts. ${ }^{76}$ However, side effects of steroids are an important cause of ocular complications, whereas efficacy in cases of noninflammatory-mediated corneal neovascularisation is limited. Hence, it appears desirable to target molecular factors of corneal angiogenesis more selectively, as occurs already in cancer treatment outside the eye and in macular disease. This field is currently emerging; important milestones are pointed out in the following section.

Translational aspects of corneal angiogenesis and clinical experience with novel therapies

In 1971, Folkman ${ }^{77}$ published a seminal article in which he suggested that tumour growth depended on angiogenesis, making it a suitable target for therapeutic interventions. Some of the work leading to this hypothesis, and much of the work undertaken since, used the cornea as an experimental model. Because of its angiogenic privilege, the cornea is suitable to show vessel-inducing effects of tumour cells or putative pro- or antiangiogenic factors in vivo. ${ }^{78}$

It is worth stressing that despite similarities, vascular growth may slightly differ between distinct anatomic locations. ${ }^{79,80}$ For instance, VEGFR-1 acts as a decoy receptor in the cornea, but induces neovascularisation in the retina, as shown by reduction of retinal neovascularisation upon experimental disruption of VEGFR-1. ${ }^{81}$ Overall, the natural avascularity of the cornea makes it quite an atypical environment to study vascular development. ${ }^{82}$

Nevertheless, experimental data from corneal angiogenesis assays contributed to the development of antiangiogenic drugs such as VEGF-inhibitors, which have been formally approved for cancer treatment, and form the mainstay for treating neovascular age-related macular degeneration. ${ }^{75}$

Curiously, development of specific antiangiogenic agents for clinical use in the anterior ocular segment remains at a less advanced stage, and use of available agents occurs 'off-label'. Actively growing vascular sprouts can be targeted using topical application of VEGF-inhibitors such as the humanised monoclonal antibody bevacizumab, initially approved for the treatment of metastatic colorectal cancer. ${ }^{72}$ The use of this and structurally related anti-VEGF antibodies have shown clinical effects in the anterior segment of the eye. A Medline search identifies a number of case series reporting the clinical use of bevacizumab in corneal neovascularisation (Table 2). At large, these studies suggest regression of neovascularisation following anti-VEGF treatment. This is despite the considerable variability in the treatment regimens used, and in the nature and severity of the conditions treated. Although most reports conclude that topical anti-VEGF therapy for corneal neovascularisation appears safe, adverse effects such as corneal thinning and reduced epithelial healing have also been acknowledged. ${ }^{83}$ These may be due to neurotrophic effects of VEGF, leading to reduction of the numerous corneal nerves when VEGF is inhibited. ${ }^{84}$ Currently, no data from randomised controlled clinical trials is available. Such studies are warranted to confirm safety and efficacy of these anti-VEGF treatment for corneal neovascularisation, with inhibition of corneal neovascularisation having been proposed as a clinically relevant endpoint. ${ }^{23}$

The only antiangiogenic compound for corneal neovascular disease, which has reached a controlled clinical testing, is an antisense oligonucleotide, designed to inhibit the expression of insulin receptor substrate-1 (IRS-1). ${ }^{85}$ IRSs are cytosolic adaptor proteins involved in the organisation of growth hormone and cytokine receptor signalling. Pre-clinical studies had shown targeting IRS-1 to inhibit corneal neovascularisation in rats, possibly mediated via downregulation of interleukin- $1 \beta .{ }^{86}$ Currently, this antisense oligonucleotide against IRS-1 is being investigated in a phase III clinical trial to determine its clinical value for topical inhibition of corneal neovascularisation. ${ }^{85,87}$

This example points out that, apart from administration of neutralising antibodies, targeting gene expression has now received some attention as a potential means to control corneal angiogenic and antiangiogenic mediators. Recent evidence from this field of study will be discussed next.

\section{Future therapies may rely on local gene therapy to influence (anti-)angiogenic factors}

With more knowledge now available regarding mediators of angiogenesis, targeting these pathways by gene therapy emerges as a promising means of fighting neovascularisation in the eye. ${ }^{28}$ This approach has been taken into clinical testing for subfoveal choroidal neovascularisation, ${ }^{80}$ with the anterior segment now striving to follow suit. Here, injection of an adenovirus vector encoding a soluble Tie- 2 receptor inhibited neovascularisation in a mouse model of corneal injury. ${ }^{88}$ In a similar vein, ex vivo transduction of corneal tissue with a lentivirus containing the human endostatin gene has been proposed as a viable method to prevent corneal graft neovascularisation and subsequent rejection in high-risk corneal transplants. ${ }^{89}$ Adenovirus-mediated transduction of corneal ECs with soluble VEGFR-1 successfully inhibited corneal neovascularisation in a rodent model..$^{90}$ The same group also used adenoassociated virus to reduce the development of 


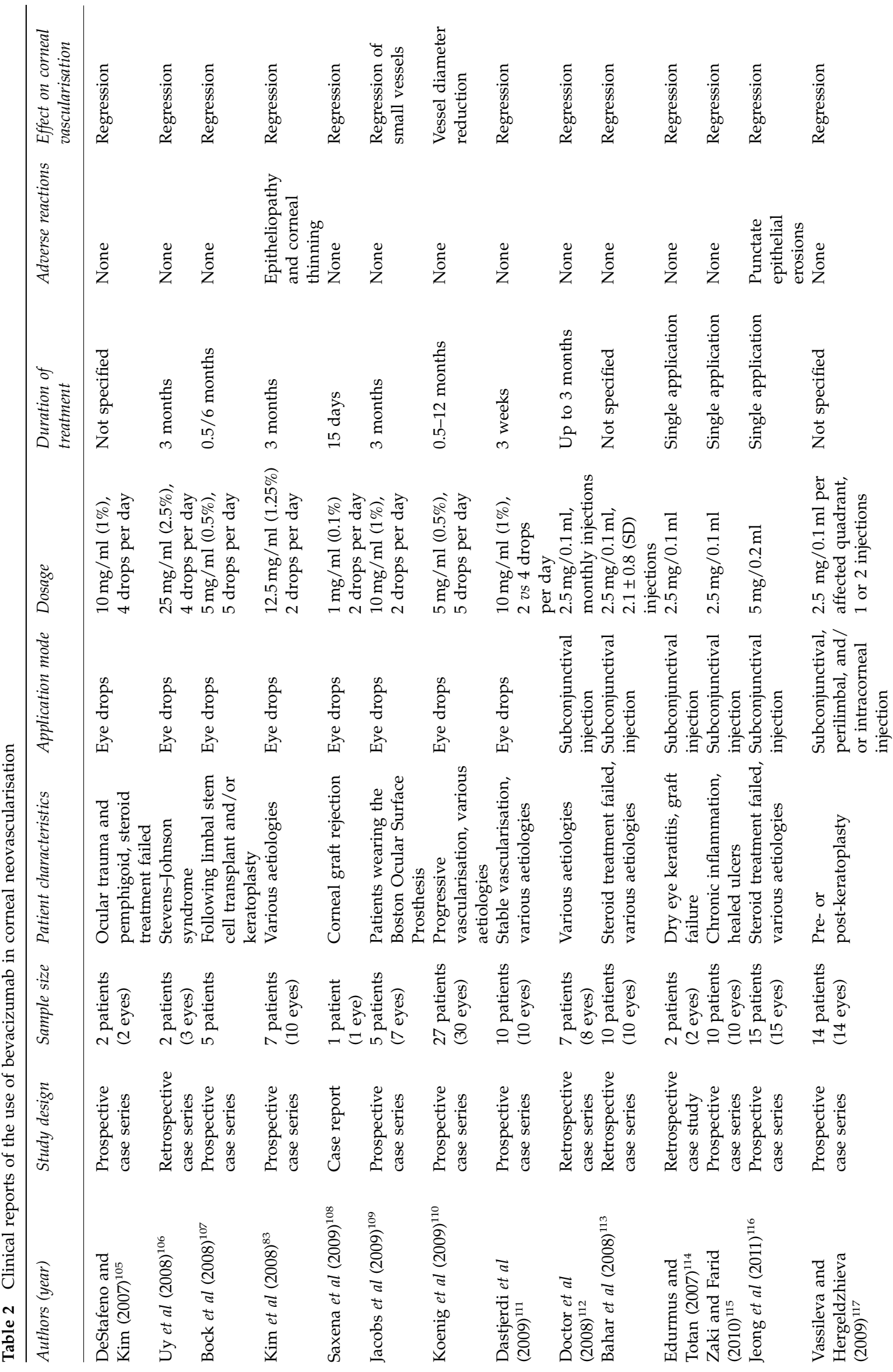


experimental corneal neovascularisation. ${ }^{91}$ A somewhat different approach uses intracorneal gene therapy to express VEGFR-1 intracellularly, leading to disruption of autocrine feedback loops, decreased VEGF secretion, and inhibition of neovascularisation..$^{92}$ This group was also able to show viability gene transfer for the same receptor using a non-viral vector. ${ }^{93}$ Another non-viral method employed experimentally for corneal antiangiogenic gene therapy was electroporation. ${ }^{94}$ Small interfering RNA (siRNA) constitutes another promising technique, which can be used locally in the eye to silence relevant genes. ${ }^{95}$ Here, difficulties may arise when it comes to determining an effective target sequence. Despite the help of online tools, the best siRNA sequence currently needs to be selected empirically. ${ }^{28}$ Nevertheless, siRNA targeting VEGF-A and/or its receptors was successfully shown to inhibit inflammation-induced corneal neovascularisation in mice. ${ }^{96}$

Interestingly, amidst all the efforts to counteract corneal neovascularisation, some authors have chosen to use gene transfer to promote corneal angiogenesis. ${ }^{97-99}$ Here, induced corneal neovascularisation serves as an assay to investigate the efficacy of gene transfer to the cornea or indeed the impact of the transfected proangiogenic gene on corneal angiogenic privilege. Through these efforts, data obtained in the cornea may - once again - support the endeavour to promote angiogenesis as a therapeutic approach towards ischaemic disorders elsewhere.

\section{Conclusions}

Corneal neovascularisation is one out of a multitude of angiogenesis-dependent diseases. ${ }^{100}$ Although many of the early studies on tumour angiogenesis were carried out using the angiogenic privilege of the cornea as a model system, ${ }^{101,102}$ anticancer drugs such as bevacizumab are now proving to be of benefit for the treatment of corneal disease. ${ }^{103}$ However, clinical data on safety and efficacy of bevacizumab is currently limited to non-randomised, largely non-comparative case series, and antiangiogenic agents developed and approved specifically for corneal neovascularisation are not yet available.

The relative accessibility and segregation of the ocular compartment makes it a good candidate for local gene therapy. ${ }^{80}$ A plethora of in vivo studies to test this approach have been carried out in recent years, so far yielding at least one multicenter trial that aims to bring a specific corneal angiogenesis inhibitor into the ophthalmic clinic. ${ }^{85}$ Future challenges include the achievement of successful delivery and stable expression of therapeutic genes. ${ }^{104}$ 
In summary, increased understanding of molecules relevant in vascular development is on the cusp of translating into specific therapeutic agents, which will be useful in the ophthalmic clinic to specifically target angiogenesis, and treat or prevent corneal neovascularisation. In this context, randomised controlled trials to establish safe and effective treatment regimens for these agents are obligatory.

\section{Conflict of interest}

The author declares no conflict of interest.

\section{References}

1 Lee P, Wang CC, Adamis AP. Ocular neovascularization: an epidemiologic review. Surv Ophthalmol 1998; 43: 245-269.

2 Michaelson IC. The mode of development of the vascular system of the retina. With some observations on its significance for certain retinal diseases. Trans Ophthalmol Soc UK 1948; 68: 137.

3 Campbell FW, Michaelson IC. Blood-vessel formation in the cornea. Br J Ophthalmol 1949; 33: 248-255.

4 Pardanaud L, Yassine F, Dieterlen-Lievre F. Relationship between vasculogenesis, angiogenesis and haemopoiesis during avian ontogeny. Development 1989; 105: 473-485.

5 Risau W. Mechanisms of angiogenesis. Nature 1997; 386: 671-674.

6 Choi K, Kennedy M, Kazarov A, Papadimitriou JC, Keller G. A common precursor for hematopoietic and endothelial cells. Development 1998; 125: 725-732.

7 Hiraoka N, Allen E, Apel IJ, Gyetko MR, Weiss SJ. Matrix metalloproteinases regulate neovascularization by acting as pericellular fibrinolysins. Cell 1998; 95: 365-377.

8 Gerhardt H, Golding M, Fruttiger M, Ruhrberg C, Lundkvist A, Abramsson A et al. VEGF guides angiogenic sprouting utilizing endothelial tip cell filopodia. J Cell Biol 2003; 161: 1163-1177.

9 Yancopoulos GD, Davis S, Gale NW, Rudge JS, Wiegand SJ, Holash J. Vascular-specific growth factors and blood vessel formation. Nature 2000; 407: 242-248.

10 Folkman J. Angiogenesis in cancer, vascular, rheumatoid and other disease. Nat Med 1995; 1: 27-31.

11 Dorrell M, Uusitalo-Jarvinen H, Aguilar E, Friedlander M. Ocular neovascularization: basic mechanisms and therapeutic advances. Surv Ophthalmol 2007; 52: S3-S19.

12 Hanahan D, Folkman J. Patterns and emerging mechanisms of the angiogenic switch during tumorigenesis. Cell 1996; 86: 353-364.

13 Carmeliet P. Mechanisms of angiogenesis and arteriogenesis. Nat Med 2000; 6: 389-395.

14 Burger PC, Chandler DB, Klintworth GK. Corneal neovascularization as studied by scanning electron microscopy of vascular casts. Lab Invest 1983; 48: 169-180.

15 Beebe DC. Maintaining transparency: a review of the developmental physiology and pathophysiology of two avascular tissues. Semin Cell Dev Biol 2008; 19: 125-133.

16 Pufe T, Petersen WJ, Miosge N, Goldring MB, Mentlein R, Varoga DJ et al. Endostatin/collagen XVIII-an inhibitor of angiogenesis-is expressed in cartilage and fibrocartilage. Matrix Biol 2004; 23: 267-276.
17 Yoshioka M, Yuasa S, Matsumura K, Kimura K, Shiomi T, Kimura $\mathrm{N}$ et al. Chondromodulin-I maintains cardiac valvular function by preventing angiogenesis. Nat Med 2006; 12: 1151-1159.

18 Goldberg MF. Persistent fetal vasculature (PFV): an integrated interpretation of signs and symptoms associated with persistent hyperplastic primary vitreous (PHPV). LIV Edward Jackson Memorial Lecture. Am J Ophthalmol 1997; 124: 587-626.

19 Ellenberg D, Azar DT, Hallak JA, Tobaigy F, Han KY, Jain S et al. Novel aspects of corneal angiogenic and lymphangiogenic privilege. Prog Retin Eye Res 2010; 29: 208-248.

20 Gabison E, Chang J-H, Hernández-Quintela E, Javier J, $\mathrm{Lu} \mathrm{PC}, \mathrm{Ye} \mathrm{H}$ et al. Anti-angiogenic role of angiostatin during corneal wound healing. Exp Eye Res 2004; 78: 579-589.

21 Chang JH, Gabison EE, Kato T, Azar DT. Corneal neovascularization. Curr Opin Ophthalmol 2001; 12: 242-249.

22 Azar DT. Corneal angiogenic privilege: angiogenic and antiangiogenic factors in corneal avascularity, vasculogenesis, and wound healing (an American Ophthalmological Society thesis). Trans Am Ophthalmol Soc 2006; 104: 264-302.

23 Cursiefen C, Colin J, Dana R, Diaz-Llopis M, Faraj LA, Garcia-Delpech $S$ et al. Consensus statement on indications for anti-angiogenic therapy in the management of corneal diseases associated with neovascularisation: outcome of an expert roundtable. Br J Ophthalmol 2011; e-pub ahead of print 28 June 2011; doi:10.1136/bjo.2011.204701.

24 Qazi Y, Maddula S, Ambati BK. Mediators of ocular angiogenesis. J Genet 2009; 88: 495-515.

25 Bachmann B, Taylor RS, Cursiefen C. Corneal neovascularization as a risk factor for graft failure and rejection after keratoplasty: an evidence-based metaanalysis. Ophthalmology 2010; 117: 1300-1305.e7.

26 Cursiefen C, Chen L, Dana MR, Streilein JW. Corneal lymphangiogenesis: evidence, mechanisms, and implications for corneal transplant immunology. Cornea 2003; 22: 273-281.

27 Dietrich T, Bock F, Yuen D, Hos D, Bachmann BO, Zahn G et al. Cutting edge: lymphatic vessels, not blood vessels, primarily mediate immune rejections after transplantation. J Immunol 2010; 184: 535-539.

28 Rajappa M, Saxena P, Kaur J. Ocular angiogenesis: mechanisms and recent advances in therapy. Adv Clin Chem 2010; 50: 103-121.

29 Millauer B, Wizigmann-Voos S, Schnürch H, Martinez R, Møller NP, Risau W et al. High affinity VEGF binding and developmental expression suggest Flk-1 as a major regulator of vasculogenesis and angiogenesis. Cell 1993; 72: 835-846.

30 Leung DW, Cachianes G, Kuang WJ, Goeddel DV, Ferrara $\mathrm{N}$. Vascular endothelial growth factor is a secreted angiogenic mitogen. Science 1989; 246: 1306-1309.

31 Ferrara N, Carver-Moore K, Chen H, Dowd M, Lu L, $\mathrm{O}^{\prime}$ Shea KS et al. Heterozygous embryonic lethality induced by targeted inactivation of the VEGF gene. Nature 1996; 380: 439-442.

32 Terman BI, Dougher-Vermazen M, Carrion ME, Dimitrov D, Armellino DC, Gospodarowicz D et al. Identification of the KDR tyrosine kinase as a receptor for vascular endothelial cell growth factor. Biochem Biophys Res Commun 1992; 187: 1579-1586. 
33 Penn JS, Madan A, Caldwell RB, Bartoli M, Caldwell RW, Hartnett ME. Vascular endothelial growth factor in eye disease. Prog Retin Eye Res 2008; 27: 331-371.

34 Kaipainen A, Korhonen J, Pajusola K, Aprelikova O, Persico MG, Terman BI et al. The related FLT4, FLT1, and KDR receptor tyrosine kinases show distinct expression patterns in human fetal endothelial cells. J Exp Med 1993; 178: 2077-2088.

35 Binétruy-Tournaire R, Demangel C, Malavaud B, Vassy R, Rouyre S, Kraemer $\mathrm{M}$ et al. Identification of a peptide blocking vascular endothelial growth factor (VEGF)mediated angiogenesis. EMBO J 2000; 19: 1525-1533.

36 Amano S, Rohan R, Kuroki M, Tolentino M, Adamis AP. Requirement for vascular endothelial growth factor in wound- and inflammation-related corneal neovascularization Invest Ophthalmol Vis Sci 1998; 39: 18-22.

37 Bock F, Onderka J, Dietrich T, Bachmann B, Pytowski B, Cursiefen C. Blockade of VEGFR3-signalling specifically inhibits lymphangiogenesis in inflammatory corneal neovascularisation. Graefes Arch Clin Exp Ophthalmol 2008; 246: 115-119.

38 Cheng T, Cao W, Wen R, Steinberg RH, LaVail MM. Prostaglandin E2 induces vascular endothelial growth factor and basic fibroblast growth factor mRNA expression in cultured rat Müller cells. Invest Ophthalmol Vis Sci 1998; 39: 581-591.

39 Behzadian MA, Wang XL, Al-Shabrawey M, Shabrawey M, Caldwell RB. Effects of hypoxia on glial cell expression of angiogenesis-regulating factors VEGF and TGF-beta. Glia 1998; 24: 216-225.

40 Kvanta A, Sarman S, Fagerholm P, Seregard S, Steen B. Expression of matrix metalloproteinase-2 (MMP-2) and vascular endothelial growth factor (VEGF) in inflammation-associated corneal neovascularization. Exp Eye Res 2000; 70: 419-428.

41 Mastyugin V, Mosaed S, Bonazzi A, Dunn MW, Schwartzman ML. Corneal epithelial VEGF and cytochrome P450 4B1 expression in a rabbit model of closed eye contact lens wear. Curr Eye Res 2001; 23: 1-10.

42 Terranova VP, DiFlorio R, Lyall RM, Hic S, Friesel R, Maciag T. Human endothelial cells are chemotactic to endothelial cell growth factor and heparin. J Cell Biol 1985; 101: 2330-2334.

43 Gospodarowicz D, Abraham JA, Schilling J. Isolation and characterization of a vascular endothelial cell mitogen produced by pituitary-derived folliculo stellate cells. Proc Natl Acad Sci USA 1989; 86: 7311-7315.

44 Soubrane G, Jerdan J, Karpouzas I, Fayein NA, Glaser B, Coscas $\mathrm{G}$ et al. Binding of basic fibroblast growth factor to normal and neovascularized rabbit cornea. Invest Ophthalmol Vis Sci 1990; 31: 323-333.

45 Presta M, Dell'Era P, Mitola S, Moroni E, Ronca R, Rusnati M. Fibroblast growth factor/fibroblast growth factor receptor system in angiogenesis. Cytokine Growth Factor Rev 2005; 16: 159-178.

46 Murakami M, Simons M. Fibroblast growth factor regulation of neovascularization. Curr Opin Hematol 2008; 15: $215-220$.

47 Onguchi T, Han KY, Chang J-H, Azar DT. Membrane type-1 matrix metalloproteinase potentiates basic fibroblast growth factor-induced corneal neovascularization. Am J Pathol 2009; 174: 1564-1571.

48 Bergers G, Brekken R, McMahon G, Vu TH, Itoh T, Tamaki K et al. Matrix metalloproteinase-9 triggers the angiogenic switch during carcinogenesis. Nat Cell Biol 2000; 2: 737-744.

49 Lindahl P, Johansson BR, Levéen P, Betsholtz C. Pericyte loss and microaneurysm formation in PDGF-B-deficient mice. Science 1997; 277: 242-245.

50 Abramsson A, Lindblom P, Betsholtz C. Endothelial and nonendothelial sources of PDGF-B regulate pericyte recruitment and influence vascular pattern formation in tumors. J Clin Invest 2003; 112: 1142-1151.

51 Glade Bender J, Cooney EM, Kandel JJ, Yamashiro DJ. Vascular remodeling and clinical resistance to antiangiogenic cancer therapy. Drug Resist Updat 2004; 7: 289-300.

52 Pérez-Santonja JJ, Campos-Mollo E, Lledó-Riquelme M, Javaloy J, Alió JL. Inhibition of corneal neovascularization by topical bevacizumab (anti-VEGF) and Sunitinib (Anti-VEGF and Anti-PDGF) in an animal model. Am J Ophthalmol 2010; 150: 519-528.e1.

53 Visconti RP, Richardson CD, Sato TN. Orchestration of angiogenesis and arteriovenous contribution by angiopoietins and vascular endothelial growth factor (VEGF). Proc Natl Acad Sci USA 2002; 99: 8219-8224.

54 Coxon A, Bready J, Min H, Kaufman S, Leal J, Yu D et al. Context-dependent role of angiopoietin-1 inhibition in the suppression of angiogenesis and tumor growth: implications for AMG 386, an angiopoietin-1/2neutralizing peptibody. Mol Cancer Ther 2010; 9: 2641-2651.

55 Ambati BK, Nozaki M, Singh N, Takeda A, Jani PD, Suthar $\mathrm{T}$ et al. Corneal avascularity is due to soluble VEGF receptor-1. Nature 2006; 443: 993-997.

56 Ambati BK, Patterson E, Jani P, Jenkins C, Higgins E, Singh $\mathrm{N}$ et al. Soluble vascular endothelial growth factor receptor-1 contributes to the corneal antiangiogenic barrier. Br J Ophthalmol 2007; 91: 505-508.

57 Cursiefen C, Chen L, Saint-Geniez M, Hamrah P, Jin Y, Rashid $\mathrm{S}$ et al. Nonvascular VEGF receptor 3 expression by corneal epithelium maintains avascularity and vision. Proc Natl Acad Sci USA 2006; 103: 11405-11410.

58 Makino Y, Cao R, Svensson K, Bertilsson G, Asman M, Tanaka $\mathrm{H}$ et al. Inhibitory PAS domain protein is a negative regulator of hypoxia-inducible gene expression. Nature 2001; 414: 550-554.

59 Dawson DW, Volpert OV, Gillis P, Crawford SE, Xu H, Benedict $\mathrm{W}$ et al. Pigment epithelium-derived factor: a potent inhibitor of angiogenesis. Science 1999; 285: 245-248.

60 Karakousis PC, John SK, Behling KC, Surace EM, Smith JE, Hendrickson A et al. Localization of pigment epithelium derived factor (PEDF) in developing and adult human ocular tissues. Mol Vis 2001; 7: 154-163.

61 Abdiu O, Van Setten G. Antiangiogenic activity in tears: presence of pigment-epithelium-derived factor. New insights and preliminary results. Ophthalmic Res 2008; 40: $16-18$.

62 O'Reilly MS, Holmgren L, Shing Y, Chen C, Rosenthal RA, Moses $\mathrm{M}$ et al. Angiostatin: a novel angiogenesis inhibitor that mediates the suppression of metastases by a Lewis lung carcinoma. Cell 1994; 79: 315-328.

63 Twining SS, Wilson PM, Ngamkitidechakul C. Extrahepatic synthesis of plasminogen in the human cornea is up-regulated by interleukins-1alpha and -1beta. Biochem I 1999; 339( Pt 3): 705-712.

64 Ambati BK, Joussen AM, Ambati J, Moromizato Y, Guha C, Javaherian $\mathrm{K}$ et al. Angiostatin inhibits and regresses 
corneal neovascularization. Arch Ophthalmol 2002; 120: 1063-1068.

65 Tonini T, Rossi F, Claudio PP. Molecular basis of angiogenesis and cancer. Oncogene 2003; 22: 6549-6556.

66 Lin H-C, Chang J-H, Jain S, Gabison EE, Kure T, Kato T et al. Matrilysin cleavage of corneal collagen type XVIII $\mathrm{NC} 1$ domain and generation of a 28-kDa fragment. Invest Ophthalmol Vis Sci 2001; 42: 2517-2524.

67 O'Reilly MS, Wiederschain D, Stetler-Stevenson WG, Folkman J, Moses MA. Regulation of angiostatin production by matrix metalloproteinase- 2 in a model of concomitant resistance. J Biol Chem 1999; 274: 29568-29571.

68 Armstrong LC, Bornstein P. Thrombospondins 1 and 2 function as inhibitors of angiogenesis. Matrix Biol 2003; 22: 63-71.

69 Cursiefen C, Masli S, Ng TF, Dana MR, Bornstein P, Lawler $\mathrm{J}$ et al. Roles of thrombospondin-1 and -2 in regulating corneal and iris angiogenesis. Invest Ophthalmol Vis Sci 2004; 45: 1117-1124.

70 Volpert OV, Tolsma SS, Pellerin S, Feige JJ, Chen H, Mosher DF et al. Inhibition of angiogenesis by thrombospondin-2. Biochem Biophys Res Commun 1995; 217: 326-332.

71 Oshima Y, Oshima S, Nambu H, Kachi S, Takahashi K, Umeda $\mathrm{N}$ et al. Different effects of angiopoietin-2 in different vascular beds: new vessels are most sensitive. FASEB J 2005; 19: 963-965.

72 Lin C-T, Hu F-R, Kuo K-T, Chen YM, Chu HS, Lin YH et al. The different effects of early and late bevacizumab (Avastin) injection on inhibiting corneal neovascularization and conjunctivalization in rabbit limbal insufficiency. Invest Ophthalmol Vis Sci 2010; 51: 6277-6285.

73 Pillai CT, Dua HS, Hossain P. Fine needle diathermy occlusion of corneal vessels. Invest Ophthalmol Vis Sci 2000; 41: 2148-2153.

74 Cursiefen C, Hofmann-Rummelt C, Küchle M, SchlötzerSchrehardt U. Pericyte recruitment in human corneal angiogenesis: an ultrastructural study with clinicopathological correlation. Br J Ophthalmol 2003; 87: 101-106.

75 Regenfuss B, Bock F, Parthasarathy A, Cursiefen C. Corneal (lymph)angiogenesis-from bedside to bench and back: a tribute to Judah Folkman. Lymphat Res Biol 2008; 6: 191-201.

76 Hos D, Saban DR, Bock F, Regenfuss B, Onderka J, Masli S et al. Suppression of inflammatory corneal lymphangiogenesis by application of topical corticosteroids. Arch Ophthalmol 2011; 129(4): 445-452.

77 Folkman J. Tumor angiogenesis: therapeutic implications. N Engl J Med 1971; 285: 1182-1186.

78 Kenyon BM, Voest EE, Chen CC, Flynn E, Folkman J, $\mathrm{D}^{\prime}$ Amato RJ et al. A model of angiogenesis in the mouse cornea. Invest Ophthalmol Vis Sci 1996; 37: 1625-1632.

79 Campochiaro PA. Ocular versus extraocular neovascularization: mirror images or vague resemblances. Invest Ophthalmol Vis Sci 2006; 47: 462-474.

80 Campochiaro PA. Potential applications for RNAi to probe pathogenesis and develop new treatments for ocular disorders. Gene Ther 2006; 13: 559-562.

81 Luttun A, Tjwa M, Moons L, Wu Y, Angelillo-Scherrer A, Liao $\mathrm{F}$ et al. Revascularization of ischemic tissues by PlGF treatment, and inhibition of tumor angiogenesis, arthritis and atherosclerosis by anti-Flt1. Nat Med 2002; 8: 831-840.

82 Auerbach R, Akhtar N, Lewis RL, Shinners BL. Angiogenesis assays: problems and pitfalls. Cancer Metastasis Rev 2000; 19: 167-172.
83 Kim SW, Ha BJ, Kim EK, Tchah H, Kim TI. The effect of topical bevacizumab on corneal neovascularization. Ophthalmology 2008; 115: e33-e38.

$84 \mathrm{Yu}$ CQ, Zhang M, Matis KI, Kim C, Rosenblatt MI. Vascular endothelial growth factor mediates corneal nerve repair. Invest Ophthalmol Vis Sci 2008; 49: 3870-3878.

85 Cursiefen C, Bock F, Horn FK, Kruse FE, Seitz B, Borderie V et al. GS-101 antisense oligonucleotide eye drops inhibit corneal neovascularization: interim results of a randomized phase II trial. Ophthalmology 2009; 116: 1630-1637.

86 Andrieu-Soler C, Berdugo M, Doat M, Courtois Y, BenEzra D, Behar-Cohen F. Downregulation of IRS-1 expression causes inhibition of corneal angiogenesis. Invest Ophthalmol Vis Sci 2005; 46: 4072-4078.

87 Bock F, Regenfuß B, Cursiefen C. [Antiangiogenic therapy at the ocular surface: When, what and why?]. Ophthalmologe 2011; 108: 230-236.

88 Singh N, Macnamara E, Rashid S, Ambati J, Kontos CD, Higgins E et al. Systemic soluble Tie2 expression inhibits and regresses corneal neovascularization. Biochem Biophys Res Commun 2005; 332: 194-199.

89 Murthy RC, McFarland TJ, Yoken J, Chen S, Barone C, Burke $\mathrm{D}$ et al. Corneal transduction to inhibit angiogenesis and graft failure. Invest Ophthalmol Vis Sci 2003; 44: 1837-1842.

90 Lai CM, Brankov M, Zaknich T, Lai YK, Shen WY, Constable IJ et al. Inhibition of angiogenesis by adenovirusmediated sFlt-1 expression in a rat model of corneal neovascularization. Hum Gene Ther 2001; 12: 1299-1310.

91 Lai YK, Shen WY, Brankov M, Lai CM, Constable IJ, Rakoczy PE. Potential long-term inhibition of ocular neovascularisation by recombinant adeno-associated virus-mediated secretion gene therapy. Gene Ther 2002; 9: 804-813.

92 Singh N, Amin S, Richter E, Rashid S, Scoglietti V, Jani PD et al. Flt-1 intraceptors inhibit hypoxia-induced VEGF expression in vitro and corneal neovascularization in vivo. Invest Ophthalmol Vis Sci 2005; 46: 1647-1652.

93 Jani PD, Singh N, Jenkins C, Raghava S, Mo Y, Amin S et al. Nanoparticles sustain expression of Flt intraceptors in the cornea and inhibit injury-induced corneal angiogenesis. Invest Ophthalmol Vis Sci 2007; 48: 2030-2036.

$94 \mathrm{Yu} \mathrm{W-Z,} \mathrm{Li} \mathrm{X-X,} \mathrm{She} \mathrm{H-C,} \mathrm{He} \mathrm{PY,} \mathrm{Dong} \mathrm{JQ,} \mathrm{Rui} \mathrm{M} \mathrm{et} \mathrm{al.}$ Gene transfer of kringle 5 of plasminogen by electroporation inhibits corneal neovascularization. Ophthalmic Res 2003; 35: 239-246.

95 Reich SJ, Fosnot J, Kuroki A, Tang W, Yang X, Maguire AM et al. Small interfering RNA (siRNA) targeting VEGF effectively inhibits ocular neovascularization in a mouse model. Mol Vis 2003; 9: 210-216.

96 Kim B, Tang Q, Biswas PS, Xu J, Schiffelers RM, Xie FY et al. Inhibition of ocular angiogenesis by siRNA targeting vascular endothelial growth factor pathway genes: therapeutic strategy for herpetic stromal keratitis. Am J Pathol 2004; 165: 2177-2185.

97 Stechschulte SU, Joussen AM, von Recum HA, Poulaki V, Moromizato Y, Yuan J et al. Rapid ocular angiogenic control via naked DNA delivery to cornea. Invest Ophthalmol Vis Sci 2001; 42: 1975-1979.

98 Kuo C-N, Yang L-C, Wu P-C, Kuo HK, Kuo CJ, Tai MH. Dehydrated form of plasmid expressing basic fibroblast growth factor-polyethylenimine complex is a novel and accurate method for gene transfer to the cornea. Curr Eye Res 2005; 30: 1015-1024. 
99 Mezentsev A, Mastyugin V, Seta F, Ashkar S, Kemp R Reddy DS et al. Transfection of cytochrome P4504B1 into the cornea increases angiogenic activity of the limbal vessels. J Pharmacol Exp Ther 2005; 315: 42-50.

100 Folkman J. Angiogenesis: an organizing principle for drug discovery? Nat Rev Drug Discov 2007; 6: 273-286.

101 Auerbach R, Arensman R, Kubai L, Folkman J. Tumorinduced angiogenesis: lack of inhibition by irradiation. Int J Cancer 1975; 15: 241-245.

102 Gimbrone MA, Cotran RS, Leapman SB, Folkman J. Tumor growth and neovascularization: an experimental model using the rabbit cornea. J Natl Cancer Inst 1974; 52: 413-427.

103 Bock F, Onderka J, Dietrich T, Bachmann B, Kruse FE, Paschke $\mathrm{M}$ et al. Bevacizumab as a potent inhibitor of inflammatory corneal angiogenesis and lymphangiogenesis. Invest Ophthalmol Vis Sci 2007; 48: 2545-2552.

104 Klausner EA, Peer D, Chapman RL, Multack RF, Andurkar SV. Corneal gene therapy. J Controlled Release 2007; 124: 107-133.

105 DeStafeno JJ, Kim T. Topical bevacizumab therapy for corneal neovascularization. Arch Ophthalmol 2007; 125. 834-836.

106 Uy HS, Chan PS, Ang RE. Topical bevacizumab and ocular surface neovascularization in patients with stevensjohnson syndrome. Cornea 2008; 27: 70-73.

107 Bock F, König Y, Kruse F, Baier M, Cursiefen C. Bevacizumab (Avastin) eye drops inhibit corneal neovascularization. Graefes Arch Clin Exp Ophthalmol 2008; 246: 281-284

108 Saxena S, Kishore P, Pandey S, Khattri M, Kumar D. Topical bevacizumab for corneal neovascularization after penetrating keratoplasty. Eur J Ophthalmol 2009; 19: 870-872.

109 Lim M, Jacobs DS, Rosenthal P, Carrasquillo KG. The Boston Ocular Surface Prosthesis as a novel drug delivery system for bevacizumab. Semin Ophthalmol 2009; 24: 149-155.
110 Koenig Y, Bock F, Horn F, Kruse F, Straub K, Cursiefen C. Short- and long-term safety profile and efficacy of topical bevacizumab (Avastin) eye drops against corneal neovascularization. Graefes Arch Clin Exp Ophthalmol 2009; 247(10): 1375-1382.

111 Dastjerdi MH, Al-Arfaj KM, Nallasamy N, Hamrah P, Jurkunas UV, Pineda 2nd R et al. Topical bevacizumab in the treatment of corneal neovascularization: results of a prospective, open-label, noncomparative study. Arch Ophthalmol 2009; 127: 381-389.

112 Doctor PP, Bhat PV, Foster CS. Subconjunctival bevacizumab for corneal neovascularization. Cornea 2008; 27: 992-995.

113 Bahar I, Kaiserman I, McAllum P, Rootman D, Slomovic A. Subconjunctival bevacizumab injection for corneal neovascularization. Cornea 2008; 27: 142-147.

114 Erdurmus M, Totan Y. Subconjunctival bevacizumab for corneal neovascularization. Graefes Arch Clin Exp Ophthalmol 2007; 245: 1577-1579.

115 Zaki AA, Farid SF. Subconjunctival bevacizumab for corneal neovascularization. Acta Ophthalmol 2010; 88: 868-871.

116 Jeong JH, Chun YS, Kim ES, Kim JC. Compensatory growth factor and cytokine response in tears after subconjunctival bevacizumab injection. Cornea 2011; 30: 1071-1077.

117 Vassileva PI, Hergeldzhieva TG. Avastin use in high risk corneal transplantation. Graefes Arch Clin Exp Ophthalmol 2009; 247: 1701-1706.

118 Oh JY, Kim MK, Wee WR. Subconjunctival and intracorneal bevacizumab injection for corneal neovascularization in lipid keratopathy. Cornea 2009; 28: 1070-1073.

119 Yeung SN, Lichtinger A, Kim P, Amiran MD, Slomovic AR. Combined use of subconjunctival and intracorneal bevacizumab injection for corneal neovascularization. Cornea 2011; 30: 1110-1114. 